\title{
Maternal and perinatal outcomes in women with advanced maternal age affected by SARS-CoV-2 infection (Phase-2): The WAPM (World Association of Perinatal Medicine) Working Group on COVID-19
}

\author{
Francesco D'Antonio ${ }^{1}$ (D) , Cihat Şen² (iD), Daniel Di Mascio ${ }^{3}$ (D) , Alberto Galindo ${ }^{4}$ (D), Cecilia Villalain ${ }^{4}$ (iD) , \\ Ignacio Herraiz ${ }^{4}$ (D) ; WAPM Working Group on COVID-19* \\ ${ }^{1}$ Center for Fetal Care and High-risk Pregnancy, University of Chieti, Chieti, Italy \\ ${ }_{2}^{2}$ erinatal Medicine Foundation \& Department of Perinatal Medicine, Memorial Bahçelievler Hospital, Istanbul, Turkey \\ ${ }^{3}$ Department of Maternal and Child Health and Urological Sciences, Sapienza University of Rome, Rome, Italy \\ ${ }^{4}$ Fetal Medicine Unit - Maternal and Child Health and Development Network, Hospital Universitario 12 de Octubre, Madrid, Spain
}

\begin{abstract}
Objective: To elucidate the role of advanced maternal age (AMA) in determining the outcome of pregnancies complicated by SARS$\mathrm{CoV}-2$ infection.

Methods: Multinational cohort study included women with laboratory-confirmed SARS-CoV-2 infection from 76 centers in 27 different countries in Europe, United States, South America, Asia and Australia from 04 April 2020 till 28 October 2020. The primary outcome was a composite measure of maternal mortality and morbidity including admission to intensive care unit (ICU), use of mechanical ventilation (defined as intubation, need for continuous positive airway pressure, extra-corporeal membrane oxygenation), severe respiratory symptoms (including dyspnea and shortness of breath) or death.

Results: Eight hundred and eighty seven pregnant women were included in the study who were positive SARS-CoV-2 results by RTPCR (reverse transcriptase-polymerase chain reaction) on their nasal and pharyngeal swab specimens ( 235 with and 652 with no AMA). The risk of composite adverse maternal outcome was higher in AMA group compared to that of under 35 years of age group, with an OR of 1.99 (95\% CI 1.4-2.9; $\mathrm{p}=0.002)$. Likewise, women $>35$ years were also at higher risk of hospital admission (OR: 1.88, 95\% CI 1.4-2.5; $<<0.001$ ), presence of severe respiratory symptoms (OR: $1.53,95 \%$ CI $1.0-2.3$; $\mathrm{p}=0.04$ ) and/or admission to ICU (OR: 2.00, 95\% CI 1.1-3.7; $\mathrm{p}=0.003$ ); however, no difference was observed in terms of perinatal outcome risk. Conclusion: Advanced maternal age is an independent risk factor for adverse maternal outcome in pregnancies complicated by SARS$\mathrm{CoV}-2$ infection. Accurate risk stratification of women presenting with suspected SARS-CoV-2 infection in pregnancy is warranted in order to identify a subset of women who may benefit from a personalized management, including elective hospitalization and/or prolonged surveillance in order to improve maternal outcome.
\end{abstract}

Keywords: SARS-CoV-2, COVID-19, Coronavirus, infection, pregnancy.
Özet: SARS-CoV-2 enfeksiyonundan etkilenmis ileri anne yaşına sahip kadınlarda maternal ve perinatal sonuçlar (Faz 2): WAPM (Dünya Perinatal Tıp Birliği) COVID-19 Çalışma Grubu

Amaç: SARS-CoV-2 enfeksiyonu ile komplike gebeliklerin sonucunu belirlemede ileri anne yaşının (İAY) rolüne 1şık tutmak.

Yöntem: Çok uluslu kohort çalışmasına, 4 Nisan 2020 ile 28 Ekim 2020 tarihleri arasında Avrupa, ABD, Güney Amerika, Asya ve Avustralya'daki 27 farklı ülkede bulunan 76 merkezden laboratuvar teyitli SARS-CoV-2 enfeksiyonlu kadınlar dahil edildi. Primer sonuç, yoğum bakım ünitesine (YBÜ) yatıs, mekanik ventilasyon kullanımı (entübasyon, sürekli pozitif hava yolu basıncı ihtiyaci, ekstrakorporeal membran oksijenizasyonu olarak tanımlanmıstır), siddetli respiratuvar semptomlar (dispne ve nefes darlığı dahil) veya ölüm dahil maternal mortalite ve morbiditenin bileşik ölçümüydü.

Bulgular: Çalışmaya, nazal ve faringeal sürüntü örneklerinde RTPCR (ters transkriptaz polimeraz zincir reaksiyonu) ile pozitif SARS-CoV-2 sonuçlarına sahip 887 gebe çalıșmaya dahil edildi (ileri anne yaşına sahip olan 235 olgu ve ileri anne yaşına sahip olmayan $652 \mathrm{olgu})$. Bileşik advers maternal sonuç riski, 35 yas altındaki gruba kıyasla 1.99 OR (olasılık oranı) ile (\%95 CU 1.4-2.9; $\mathrm{p}=0.002)$ IAY grubunda daha yüksekti. Benzer şekilde 35 yaşından büyük kadinlarda da hastaneye yatıs (OR: 1.88, \%95 GA 1.4-2.5; p<0.001), siddetli respiratuvar semptom varlığ1 (OR: 1.53, \%95 GA 1.0-2.3; $\mathrm{p}=0.04)$ ve/veya YBÜ'ye yatı̧ (OR: 2.00 , \%95 GA 1.1-3.7; p=0.003) riski daha yüksekti, ancak perinatal sonuç riski bakımından hiçbir fark bulunmadı.

Sonuc: İleri anne yaș1, SARS-CoV-2 enfeksiyonuyla komplike gebeliklerde advers maternal sonuç için bağımsız bir risk faktörüdür. Maternal sonucu iyileştirebilmek için, elektif hospitalizasyon ve/veya uzun süreli takip dahil kişiselleştirilmiş bir yönetimden faydalanabilecek kadınların alt kümesini tespit edebilmek amaciyla gebelikte SARS-CoV-2 enfeksiyonu olduğundan şüphelenilen kadınlarda doğru risk sınıflandırması gereklidir.

Anahtar sözcükler: SARS-CoV-2, COVID-19, Koronavirüs, enfeksiyon, gebelik.

Correspondence: Francesco D'Antonio, MD. Center for Fetal Care and High-risk Pregnancy, University of Chieti, Chieti, Italy. e-mail: dantoniofra@gmail.com / Received: February 1, 2021; Accepted: March 9, 2021

How to cite this article: D'Antonio F, Sen C, Di Mascio D, Galindo A, Villalain C, Herraiz I, et al.; WAPM (World Association of Perinatal Medicine) Working Group on COVID-19. Maternal and perinatal outcomes in women with advanced maternal age affected by SARS-COV-2 infection (Phase-2): The WAPM (World Association of Perinatal Medicine) Working Group on COVID-19. Perinatal Journal 2021;29(1):71-78. doi:10.2399/prn.21.0291011 *Full author list and affiliations are listed at the end of the article.

ORCID ID: F. D'Antonio 0000-0002-5178-3354; C. Şen 0000-0002-2822-6840; D. Di Mascio 0000-0002-6560-3393; 


\section{Introduction}

Severe Acute Respiratory Syndrome Coronavirus 2 (SARS-CoV-2) infection spread towards the end of 2019 and is still a major public health problem. New cases of infection, hospitalization, admission to Intensive Care Unit (ICU) and death toll are increasing on a daily basis worldwide. ${ }^{[1,2]}$ From the beginning of pandemic, pregnancy has been claimed to be potentially be associated with a higher burden of maternal mortality and morbidity compared to the general population, due to the peculiar cardiovascular and respiratory maternal adaptations occurring during pregnancy. ${ }^{[3,4]}$

Several cohort studies and systematic reviews evaluating the course of SARS-CoV-2 in pregnancy for maternal and perinatal outcomes have been published so far. ${ }^{[5-8]}$ Despite the reassuring low rates of maternalperinatal mortality and vertical transmission, in pregnancy, the risk of maternal admission to ICU appears to be higher, than that of age-matched non-pregnant women. ${ }^{[8-10]}$

The severity of SARS-CoV-2 infection in pregnancy has been reported to be associated with several risk factors. Among these, maternal age has been found to be an independent additional risk for adverse maternal outcome. $^{[9]}$ Still, the data for the relation between maternal age and outcome of pregnancies complicated by this infection is inconsistent. The aim of this study was to report the outcome of SARS-CoV-2 infection in pregnancies with AMA in a multinational cohort of pregnant women who were tested positive for SARS$\mathrm{CoV}-2$ infection.

\section{Methods}

This was a multinational, prospective cohort study involving pregnant women with a laboratory-confirmed SARS-CoV-2 infection, diagnosed from April the 4th, 2020 till October 28th, 2020. This study was designed as an open and web-based database study in 76 centers from 27 different countries (Argentina, Australia, Belgium, Brazil, Bulgaria, Colombia, Czech Republic, Chile, Finland, Germany, Greece, Equatorial Guinea, India, Israel, Italy, Mexico, North Macedonia, Peru, Portugal, Republic of Kosovo, Romania, Russia, Serbia, Slovenia, Spain, Turkey, and The United States) by the World Association of Perinatal Medicine (WAPM) COVID-19 Study Group. The study was endorsed by
WAPM. Ethical approval for the study was obtained from the Ethical Committee of Federico II University of Naples (nr.145/2020). The first phase of the study has already been published and comprised the data from April 4th, 2020 till June 1st, 2020. ${ }^{[4]}$ Then, additional data (more details for fetal and neonatal outcome) was added and reevaluated by contributors for WAPM COVID-19 Study Phase-2 new database. Only confirmed cases with PCR were included in the evaluation. The cases with clinical diagnosis without positive PCR test were excluded.

SARS-CoV-2 was diagnosed on the basis of The World Health Organization (WHO) interim guidance. ${ }^{[11]}$ A confirmed case of SARS-CoV-2 was defined as a positive result on real-time reverse-transcriptasepolymerase-chain-reaction (RT-PCR) assay of nasal and pharyngeal swab specimens. ${ }^{[11,12]}$

In the included centers, women were tested with RT-PCR of nasal and pharyngeal swab mostly because of having symptoms or history of exposure.

Neonates of mothers with positive SARS-CoV-2 results were usually tested within 24 hours after delivery by oro-nasopharyngeal swab RT-PCR. Data on recent exposure history, clinical symptoms or signs, laboratory findings, maternal and perinatal outcomes were collected. All medical records were anonymized and sent to the coordinator center at University of Naples Federico II (Naples, Italy) through the WAPM data platform. Data were entered into a computerized database and cross-checked. In case of missing data, requests for clarification were sent to the coordinator of each participating center.

The primary outcome was to compare the rates of maternal mortality and morbidity (admission to intensive care unit [ICU], use of mechanical ventilation [defined as intubation, need for continuous positive airway pressure, extra-corporeal membrane oxygenation], severe respiratory symptoms [including dyspnea and shortness of breath]). Secondary outcomes were a composite score of adverse perinatal outcome, including miscarriage, intrauterine death (IUD), neonatal death (NND), perinatal death (PND), admission to neonatal intensive care unit. Miscarriage was defined as pregnancy loss before 22 weeks of gestation, IUD as fetal loss at or after 22 weeks of gestation, while NND as death of a live-born infant within the first 28 days of life. PND was defined as IUD or NND. 
Further details on criteria for maternal admission to ICU and neonatal admission to NICU are more extensively described elsewhere. ${ }^{[4]}$

All outcomes of AMA group were compared to that of non-AMA group. For the purpose of the analysis, AMA was defined as age $>35$ years. Subgroup analysis considering women $>40$ years was also performed.

Statistical analysis was performed using Statistical Package for Social Sciences (SPSS) v. 19.0 (IBM Inc., Armonk, NY, USA) and using Stata, version 13.1 (Stata Corp., College Station, TX, USA, 2014). Continuous variables were reported as means \pm standard deviation (SD), while categorical variables as percentage. Univariate comparisons of dichotomous data were performed with the use of the Fisher's exact test with continuity correction. Comparisons between groups were performed with the use of the Student's t- test to analyze by assuming equal within-group variances for parametric data, and with the use of MannWhitney U tests for nonparametric data. Multivariate analysis was performed to evaluate potential predictors of the primary outcome. Logistic regression was reported as odds ratio (OR) and adjusted OR (aOR) with $95 \%$ confidence interval (CI). A p-value $<0.05$ was considered statistically significant.

\section{Results}

During the study period, 887 singleton viable pregnancies from 76 centers in 27 different countries, who were tested positive for SARS-CoV-2 by nasopharyngeal swab RT-PCR were included. Among these, 652 were $<35$ years old of age, 235>35 and $67>40$ years. General characteristic of the study population is reported in Table 1.

Table 1. Comparison of different characteristics in pregnant women with those with no advanced age.

\begin{tabular}{|c|c|c|c|c|c|}
\hline Characteristic & $\begin{array}{c}<35 \text { years } \\
(n=652)\end{array}$ & $\begin{array}{c}\geq 35 \text { years } \\
(n=235)\end{array}$ & p-value & $\begin{array}{c}\geq 40 \text { years } \\
\quad(n=67)\end{array}$ & p-value \\
\hline \multicolumn{6}{|l|}{ Maternal and pregnancy characteristics } \\
\hline Gestational age at diagnosis of infection (weeks) & $25.41 \pm 8.1$ & $26.35 \pm 8.9$ & 0.134 & $30.78 \pm 8.9$ & $<0.001$ \\
\hline Nulliparity & $30.5(199)$ & $44.7(105)$ & 0.001 & $43.3(29)$ & 0.039 \\
\hline Smoking before or during pregnancy & $4.6(30)$ & $0.9(2)$ & 0.007 & $1.5(1)$ & 0.349 \\
\hline High-risk pregnancies & $17.3(113)$ & $(95)$ & $<0.001$ & $67.1(45)$ & $<0.001$ \\
\hline \multicolumn{6}{|l|}{ Clinical, radiological and laboratory findings } \\
\hline Symptomatic infection & $56.1(366)$ & $64.3(151)$ & 0.039 & $58.2(39)$ & 0.797 \\
\hline Respiratory symptoms & $32.7(213)$ & $44.7(105)$ & 0.719 & $40.3(27)$ & 0.701 \\
\hline Non-respiratory symptoms & $30.7(200)$ & $34.0(80)$ & 0.368 & $31.3(21)$ & 0.601 \\
\hline Only non-respiratory symptoms & $22.5(147)$ & $19.6(46)$ & 0.358 & $17.9(12)$ & 0.442 \\
\hline Fever & $28.1(183)$ & $31.1(73)$ & 0.402 & $23.9(16)$ & 0.567 \\
\hline Cough & $23.5(153)$ & $35.7(84)$ & 0.001 & $44.8(30)$ & 0.001 \\
\hline Myalgia & $16.0(104)$ & $22.6(53)$ & 0.028 & $47.8(32)$ & 0.001 \\
\hline Anosmia & $5.4(35)$ & $9.8(23)$ & 0.030 & $7.5(5)$ & 0.409 \\
\hline Gastrointestinal symptoms & $3.5(23)$ & $1.7(4)$ & 0.190 & $1.5(1)$ & 0.717 \\
\hline Lymphopenia & $48.6(317)$ & $43.8(103)$ & 0.223 & $55.2(37)$ & 0.308 \\
\hline Thrombocytopenia & $6.0(39)$ & $8.1(19)$ & 0.282 & $9.0(6)$ & 0.297 \\
\hline Increased LDH levels & $5.7(37)$ & $6.8(16)$ & 0.523 & $11.9(8)$ & 0.059 \\
\hline \multicolumn{6}{|l|}{ Pharmacologic treatments } \\
\hline LMWH & $17.5(114)$ & $29.4(69)$ & $<0.001$ & $50.7(34)$ & $<0.001$ \\
\hline Antibiotics & $27.5(179)$ & $38.7(91)$ & 0.002 & $67.2(45)$ & $<0.001$ \\
\hline Any antiviral drug & $20.6(134)$ & $31.9(75)$ & 0.001 & $58.2(39)$ & $<0.001$ \\
\hline Hydroxychloroquine & $15.5(99)$ & $29.4(69)$ & $<0.001$ & $53.7(36)$ & 1.00 \\
\hline
\end{tabular}

LDH: lactate dehydrogenase; LMWH: low molecular weight heparin. 
There was no difference in mean gestational age at the diagnosis of the infection between AMA group and non-AMA group $(25.4 \pm 8.1$ vs $26.4 \pm 8.9$, respectively; $\mathrm{p}=0.134)$. The incidence of nulliparity $(44.7 \%$ vs $30.5 \%, \mathrm{p}=0.001$ ) and high-risk pregnancies (i.e. preexisting or gestational medical conditions complicating the pregnancy) $(40.4 \%$ vs $17.3 \%, \mathrm{p}<0.0001)$ was higher in AMA group when compared to no-AMA group. When exploring the different clinical, radiologic and laboratory findings, women in AMA group were more likely to present with a symptomatic infection $(64.3 \%$ vs $56.1 \%, \mathrm{p}=0.039$ ), while there was no difference in the occurrence of respiratory or non-respiratory symptoms, fever, lymphopenia, thrombocytopenia or increased serum LDH levels between the two study groups (Table 1).

The risk of composite adverse maternal outcome was higher in women with AMA compared to those $<35$ years (OR: 1.99, 95\% CI 1.4-2.9; p<0.001) (Table 2). Likewise, women were also at higher risk of hospital admission (OR: 1.88, 95\% CI 1.4-2.5; p<0.001), presence of severe respiratory symptoms (OR: $1.53,95 \% \mathrm{CI}$ 1.0-2.3; p=0.045), and admission to ICU (OR: 2.00, $95 \%$ CI 1.1-3.7; $\mathrm{p}=0.035$ ) while there was no difference in the risk of adverse perinatal outcome between the two groups.

When restricting the analysis to women over 40 years of age, the risk of composite adverse maternal out- come was higher in women $>40$ compared to those $<40$ years of age (OR: 2.53, 95\% CI 1.4-4.5; p=0.006). Likewise, women $>40$ had also a higher risk of in hospital admission (OR: 1.89, 95\% CI 1.1-3.1; $\mathrm{p}=0.016$ ), development of severe respiratory symptoms (OR: 2.28, 95\% CI 1.2-4.2, p=0.012), admission to ICU (OR: 3.26, 95\% CI 1.4-7.5; $\mathrm{p}=0.010)$ and/or need for invasive ventilation (OR: 4.18, 95\% CI 1.6-11.2; p=0.009). At logistic regression analysis, AMA >35 (OR: 3.12, 95\% CI 2.2-5.7; $\mathrm{p}=0.002)$, presence of a high-risk pregnancies (OR: 4.12, 95\% CI 3.1-6.311; p=0.001) and nulliparity (OR: 3.11, 95\% CI 2.9-6.2; p=0.001) were independently associated with adverse maternal outcome.

\section{Discussion}

This secondary analysis of the WAPM's multinational cohort study on pregnant women with SARS-CoV-2 from 76 different centers, showed that risks of composite adverse maternal outcome, severe respiratory symptoms and admission to ICU are higher in pregnant women with AMA than youngers.

To our knowledge, this is the first study extensively assessing the role of AMA on the outcome of pregnancies complicated by SARS-CoV-2 infection. The WAPM study was one of the largest cohort of pregnant women with SARS-CoV-2 infection, with data collected from the beginning of the pandemic. Major strengths of the study are the enrollment of only confirmed SARS-

Table 2. Comparison of the different maternal and fetal outcomes in pregnant women with those without advanced age.

\begin{tabular}{|c|c|c|c|c|c|}
\hline & $\begin{array}{c}<35 \text { years } \\
(n=652)\end{array}$ & $\begin{array}{l}\geq 35 \text { years } \\
(n=235)\end{array}$ & p-value & $\begin{array}{c}\geq 40 \text { years } \\
(n=67)\end{array}$ & p-value \\
\hline Composite adverse maternal outcome & $14.4(94)$ & $25.1(59)$ & $<0.001$ & $30.0(20)$ & 0.006 \\
\hline In hospital admission & $35.3(230)$ & $50.6(119)$ & $<0.001$ & $50.7(34)$ & 0.016 \\
\hline Severe respiratory symptoms & $12.1(79)$ & $17.4(41)$ & 0.045 & $23.9(16)$ & 0.012 \\
\hline Admission to intensive care unit & $4.0(26)$ & $7.7(18)$ & 0.035 & $11.9(8)$ & 0.010 \\
\hline Invasive ventilation & $2.3(15)$ & $4.3(10)$ & 0.165 & $9.0(6)$ & 0.009 \\
\hline Maternal death & $0.3(2)$ & $0.4(1)$ & 1.000 & $1.5(1)$ & 0.255 \\
\hline Composite adverse fetal outcome & $11.2(73)$ & $13.2(31)$ & 0.410 & $14.9(10)$ & 0.420 \\
\hline Miscarriage & $2.5(16)$ & $2.6(6)$ & 1.000 & $6.0(4)$ & 0.107 \\
\hline Intra-uterine death & $0.5(3)$ & $0.9(2)$ & 0.612 & $0(0)$ & 1.000 \\
\hline Neonatal death & $0.8(5)$ & $1.3(3)$ & 0.443 & $0(0)$ & 1.000 \\
\hline Perinatal death & $1.2(8)$ & $2.1(5)$ & 0.346 & $0(0)$ & 1.000 \\
\hline Admission to neonatal intensive care unit & $7.5(49)$ & $9.8(23)$ & 0.268 & $9.0(6)$ & 0.630 \\
\hline Vertical transmission & $0.6(4)$ & $2.1(5)$ & 0.061 & $4.5(3)$ & 0.021 \\
\hline
\end{tabular}


CoV-2 cases, large sample size, the inclusion of both tertiary centers and community hospitals from many different countries and multitude of outcomes explored.

The major limitation was that the study population came mostly from women referred for suspected SARS$\mathrm{CoV}-2$ infection, due to symptoms or exposure, and consequently tested, thus leading to an intuitively lower percentage of asymptomatic women in the study cohort. Furthermore, different income level of countries and healthcare systems, and the heterogeneity in the management of both the mother and the fetus might have independently affected perinatal outcomes.

Women who delay childbearing are at increased risk of adverse pregnancy outcome, including miscarriage, fetal anomalies, pre-eclampsia, gestational diabetes and cesarean delivery compared to getting pregnant at younger age. ${ }^{[13,14]}$ The reason for such association is likely to rely on the higher rate of chronic morbidities potentially affecting a pregnancy in advanced age.

In the present study, we reported that AMA represents an independent risk factor for adverse outcomes in pregnancies complicated by SARS-CoV-2 infection, irrespective of the presence of pregestational or gestational co-morbidities. The course of SARS-CoV-2 infection in pregnancy has been widely reported with a higher risk of maternal respiratory morbidity compared to non-pregnant counterparts, due to physiologic changes of pregnancy that might predispose them to a more severe clinical course. ${ }^{[3-9]}$

One of the largest systematic reviews recently published on this topic showed that pregnant women affected by COVID-19 were significantly more likely to need admission to ICU and invasive ventilation, compared to non-pregnant women of same reproductive age, and that increased maternal age, higher BMI, chronic hypertension and pre-existing diabetes were all significantly associated with a more severe course of SARS-CoV-2 infection in pregnancy. ${ }^{[9]}$

A likely explanation for the independent association between AMA and adverse pregnancy outcome may rely in the higher incidence of maternal chronic conditions in previous pregnancy of these women. However, the association between AMA and adverse maternal outcome persisted at logistic regression analysis, indicating an independent contribution of AMA in determining the outcome of pregnancies complicated by SARS-CoV-2 infection. Pregnancy induces marked changes in the res- piratory and cardiovascular systems that are essential for meeting the increased metabolic demands of the mother and fetus. It is plausible that relative changes in the respiratory physiology with advancing age may predispose these women to a higher risk of developing pulmonary complications when affected by SARS-CoV-2 infection.

The findings from this study support an accurate risk stratification of pregnancies complicated by SARS-CoV2 infection in order to maximize the maternal respiratory outcome. Pregnancies with co-morbidities and advanced age are at higher risk of developing complications. ${ }^{[15]}$ A prolonged observation of women presenting with mild symptoms or elective hospital admission may represent a reasonable option in order to improve maternal outcome, although this assumption would require confirmation in randomized controlled trials.

\section{Conclusion}

Advanced maternal age represents an independent risk factor for adverse maternal outcome in pregnancies complicated by SARS-CoV-2 infection. Accurate risk stratification of women presenting with suspected SARS-CoV-2 infection in pregnancy is warranted in order to identify a subset of women who may benefit of a personalized management, including prolonged surveillance or elective hospitalization, in order to improve maternal outcomes.

\section{The WAPM (The World Association of Perinatal Medicine) Working Group on COVID-19}

\section{It has been listed here accordingly to their contribution:}

Francesco D'Antonio ${ }^{1}$, Cihat Şen ${ }^{2,3}$, Daniele Di Mascio", Alberto Galindo5, Cecilia Villalain ${ }^{5}$, Ignacio Herraiz, Resul Arısoy ${ }^{3}$, Ali Ovayolu ${ }^{6}$, Hasan Eroğlu' ${ }^{6}$, Manuel Guerra Canales ${ }^{7}$, Subhashini Ladella ${ }^{8}$, Liviu Cojocaru', Özhan Turan', Şifa Turan', Eran Hadar $^{10}$, Noa A. Brzezinski-Sinai $^{10}$, Sarah Dollinger ${ }^{10}$, Ozlem Uyanıklar ${ }^{11}$, Sakine Rahimli Ocakoğlu ${ }^{11}$, Zeliha Atak ${ }^{11}$, Tanja PremruSrsen $^{12}$, Lilijana Kornhauser-Cerar ${ }^{12}$, Mirjam Druškovic ${ }^{12}$, Liana Ples ${ }^{13}$, Reyhan Gündüz ${ }^{14}$, Elif Ağaçayak ${ }^{14}$, Javier Alfonso Schvartzman ${ }^{15}$, Mercedes Negri Malbran ${ }^{15}$, Marco Liberati ${ }^{1}$, Francesca Di Sebastiano ${ }^{1}$, Ludovica Oronzi ${ }^{1}$, Chiara Cerra ${ }^{1}$, Danilo Buca ${ }^{1}$, Angelo Cagnacci ${ }^{16}$, Arianna Ramone $^{16}$, Fabio Barra ${ }^{16}$, Andrea Carosso ${ }^{17}$, Chiara Benedetto $^{17}$, Stefano Cosma ${ }^{17}$, Axelle Pintiaux ${ }^{18}$, Caroline Daelemans $^{18}$, Elena Costa ${ }^{18}$, Ayşegül Özel ${ }^{19}$, Murat 
Muhçu $^{19}$, Jesús S Jimenez Lopez ${ }^{20}$, Clara Alvarado ${ }^{21}$, Anna Luengo Piqueras ${ }^{22}$, Dolores Esteban Oliva ${ }^{22}$, Giovanni Battista Luca Schera ${ }^{23}$, Nicola Volpe ${ }^{23}$, Tiziana Frusca ${ }^{23}$, Igor Samardjiski ${ }^{24}$, Slagjana Simeonova ${ }^{24}$, Irena Aleksioska Papestiev $^{24}$, Javier Hojman ${ }^{25}$, Ilgin Türkçüoğlu ${ }^{26}$, Antonella $\mathrm{Cromi}^{27}$, Antonio Simone Laganà ${ }^{27}$, Fabio Ghezzi $^{27}$, Angelo Sirico ${ }^{28}$, Alessandra Familiari ${ }^{28}$, Giovanni Scambia $^{28}$, Zulfiya Khodjaeva Gennady T. Sukhikh ${ }^{29}$, Ksenia A. Gorina ${ }^{29}$, Renato Augusto Moreira de $\mathrm{Sa}^{30}$, Mariana $\mathrm{Vaz}^{30}$, Otto Henrique May Feuerschuette ${ }^{31}$, Anna Nunzia Della Gatta ${ }^{32}$, Aly Youssef ${ }^{32}$, Gaetana Di Donna ${ }^{32}$, Alicia Martinez-Varea ${ }^{33}$, Gabriela Loscalzo ${ }^{33}$, José Morales Rosello $^{33}$, Vedran Stefanovic ${ }^{34}$, Irmeli Nupponen ${ }^{34}$, Kaisa Nelskylä $^{34}$, Rodrigo Ayala ${ }^{35}$, Rebeca Garrote Molpeceres ${ }^{36}$, Asunción Pino Vázquez ${ }^{36}$, Fabrizio Sandri ${ }^{37}$, Ilaria Cataneo $^{37}$, Marinella Lenzi ${ }^{37}$, Esra Tuştaş Haberal ${ }^{38}$, Erasmo Huertas $^{39}$, Amadeo Sanchez ${ }^{39}$, Pedro Arango ${ }^{39}$, Amanda Bermejo ${ }^{40}$, María Monica Gonzalez Alcantara ${ }^{41}$, Gökhan Göynümer ${ }^{42}$, Erhan Okuyan ${ }^{43}$, Ciuhodaru Madalina $^{44}$, Ana Concheiro Guisan ${ }^{45}$, Alejandra Martínez Schulte $^{46}$, Valentina Esposito ${ }^{47}$, Valentina De Robertis ${ }^{48}$, Snezana Zdjelar ${ }^{49}$, Milan Lackovic ${ }^{49}$, Sladjana Mihajlovic ${ }^{49}$, Nelly Jekova $^{50}$, Gabriele Saccone ${ }^{51}$, Mehmet Musa Aslan ${ }^{52}$, Maria Carmela Di Dedda ${ }^{53}$, Maisuri Chalid ${ }^{54}$, Jose Enrique Moros Canache ${ }^{55}$, George Daskalakis ${ }^{56}$, Panos Antsaklis $^{56}$, Enrique Criado Vega ${ }^{57}$, Elisa Cueto ${ }^{58}$, Chiara Taccaliti $^{59}$, Alicia Yeliz Aykanat ${ }^{60}$, Şerife Özlem Genç ${ }^{61}$, Bernd Froessler ${ }^{62}$, Petya Angelova Radulova ${ }^{63}$, Danila Morano $^{64}$, Beatrice Bianchi ${ }^{64}$, Maria Giulia Lombana Marino $^{64}$, Gabriella Meccariello ${ }^{65}$, Bindu Rohatgi ${ }^{66}$, Antonio Schiattarella ${ }^{67}$, Maddalena Morlando ${ }^{67}$, Nicola Colacurci $^{67}$, Andrea Villasco ${ }^{68}$, Nicoletta Biglia ${ }^{68}$, Ana Luiza Santos Marques ${ }^{69}$, Alessandra Gatti ${ }^{70}$, Daniela Luvero $^{70}$, Roberto Angioli ${ }^{70}$, Alejandro Pittaro ${ }^{71}$, Albert Lila $^{72}$, Blanka Zlatohlávková ${ }^{73}$

${ }^{1}$ Centre for High-Risk Pregnancy and Fetal Care, Department of Obstetrics and Gynecology, University of Chieti, Chieti, Italy

${ }^{2}$ Perinatal Medicine Foundation, Istanbul, Turkey

${ }^{3}$ Department of Perinatal Medicine, Memorial Hospital, Istanbul, Turkey

${ }^{4}$ Department of Maternal and Child Health and Urological Sciences, Sapienza University of Rome, Rome, Italy

${ }^{5}$ Fetal Medicine Unit, Maternal and Child Health and Development Network, Department of Obstetrics and Gynecology, University Hospital 12 de Octubre, Complutense University of Madrid, Madrid, Spain

${ }^{6}$ Cengiz Gökçek Women's and Children's Hospital, Gaziantep, Turkey
${ }^{7}$ Hospital Clinico San Jose, Santiago de Chile, Chile

${ }^{8}$ Community Medical Centers, UCSF Fresno, Fresno, CA, USA

${ }^{9}$ Department of Obstetrics, Gynecology and Reproductive Science, University of Maryland Medical Center, Baltimore, MD, USA

${ }^{10}$ Helen Schneider Hospital for Women, Rabin Medical Center, Petach-Tikva and Sackler Faculty of Medicine, Tel-Aviv University, Tel-Aviv, Israel

${ }^{11}$ Bursa City Hospital, Bursa, Turkey

${ }^{12}$ Department of Perinatology, University Medical Center, Medical Faculty, University of Ljubljana, Ljubljana, Slovenia

${ }^{13}$ Department of Obstetrics and Gynecology, Saint John Hospital, UMF Carol Davila Bucharest, Bucharest, Romania

${ }^{14}$ Department of Obstetrics and Gynecology, Dicle University, Diyarbakır, Turkey

${ }^{15}$ Centro de Educación Médica e Investigaciones Clínicas "Norberto Quirno", Buenos Aires, Argentina

${ }^{16}$ Academic Unit of Obstetrics and Gynaecology, IRCCS Ospedale Policlinico San Martino, Genova, Italy

${ }^{17}$ Department of Obstetrics and Gynecology, Sant'Anna Hospital, University of Turin, Turin, Italy

${ }^{18}$ Department of Obstetrics and Gynecology, Hospital Erasme, Cliniques Universitaires de Bruxells, Brussels, Belgium

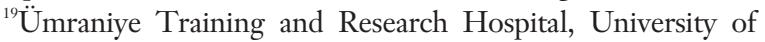
Health Sciences, Istanbul, Turkey

${ }^{20}$ Hospital Regional Universitario de Málaga, Malaga, Spain

${ }^{21}$ Clínica del Country, Bogotá, Colombia

${ }^{22}$ Hospital Universitari Germans Trias i Pujol, Barcelona, Spain

${ }^{23}$ Department of Obstetrics and Gynecology, University of Parma, Parma, Italy

${ }^{24}$ University Clinic of Obstetrics and Gynecology, Skopje, North Macedonia

${ }^{25}$ División Obstetricia, Hospital de Clínicas "José de San Martín”, Buenos Aires, Argentina

${ }^{26}$ Department of Obstetrics and Gynecology, School of Medicine, SANKO University, Gaziantep, Turkey

${ }^{27}$ Department of Obstetrics and Gynecology, "Filippo Del Ponte" Hospital, University of Insubria, Varese, Italy

${ }^{28}$ Department of Obstetrics and Gynaecology, Fondazione Policlinico Universitario A Gemelli IRCCS - Università Cattolica del Sacro Cuore, Rome, Italy

${ }^{29}$ National Medical Research Center for Obstetrics, Gynecology and Perinatology, Moscow, Russia

${ }^{30}$ Assistência Obstétrica do Grupo Perinatal, Rio de Janeiro, Brazil

${ }^{31}$ Departamento de Ginecologia e Obstetrícia, Hospital Universitário Polydoro Ernani, Santiago, Brazil

${ }^{32}$ Department of Obstetrics and Gynecology, University of Bologna, Sant'Orsola Malpighi University Hospital, Bologna, Italy

${ }^{33}$ Servicio de Obstetricia y Ginecología, Hospital Universitario y Politécnico La Fe, Valencia, Spain

${ }^{34}$ Department of Obstetrics and Gynecology, Neonatology and Intensive Care, Helsinki University Hospital and University of Helsinki, Helsinki, Finland

${ }^{35} \mathrm{ABC}$ Medical Center, Mexico City, Mexico 
${ }^{36}$ University Clinic Hospital of Valladolid, Valladolid, Spain

${ }^{37}$ Unit of Obstetrics and Gynecology, Ospedale Maggiore, Bologna, Italy

${ }^{38}$ Hisar Intercontinental Hospital, İstanbul, Turkey

${ }^{39}$ Instituto Nacional Materno Perinatal, Lima, Peru

${ }^{40}$ Hospital Universitario de Móstoles, Mostoles, Spain

${ }^{41}$ Hospital Juan A. Fernandez, Buenos Aires, Argentina

${ }^{42}$ Department of Perinatology, Faculty of Medicine, Düzce University, Düzce, Turkey

${ }^{43}$ Batman Maternity and Child Health Hospital, Batman, Turkey

${ }^{44}$ Universitatea de Medicin? şi Farmacie Grigore T. Popa Iaşi, Iaşi, Romania

${ }^{45}$ Alvaro Cunqueiro University Hospital of Vigo, Vigo, Spain

${ }^{46}$ Hospital Angeles Lomas, Mexico City, Mexico

${ }^{47}$ University of Milan, Milan, Italy

${ }^{48}$ Fetal Medicine Unit, Di Venere Hospital, Bari, Italy

${ }^{49}$ KBC Dr Dragisa Misovic - Dedinje, Belgrade, Serbia

${ }^{50}$ Department of Neonatology, Obstetrics and Gynecology, University Hospital, Sofia, Bulgaria

${ }^{51}$ Department of Neuroscience, Reproductive Sciences and Dentistry, School of Medicine, University of Naples Federico II, Naples, Italy Turkey

${ }^{52}$ Sakarya University Training and Research Hospital, Sakarya,

${ }^{53}$ Department Gynecology and Obstetrics, Fornaroli Hospital, Magenta, Italy

${ }^{54}$ Department of Obstetrics and Gynecology, Hasanuddin University, Makassar, Indonesia

${ }^{55}$ Departamento de Ginecologia y Obstetricia, Centro Medico La Paz de Bata, Bata, Ecuatorial Guinea

${ }^{56}$ Alexandra Hospital, National and Kapodistrian University of Athens, Athens, Greece

${ }^{57}$ Division of Neonatology, Hospital Clínico "San Carlos", Madrid, Spain

${ }^{58}$ Hospital Virgen de la Luz, Cuenca, Spain

${ }^{59}$ Ospedale Generale Regionale "F. Miulli", Acquaviva delle Fonti, Italy

${ }^{60}$ Department of Obstetrics and Gynecology, Istanbul University-Cerrahpaşa Medical School, Istanbul, Turkey

${ }^{61}$ Karaman Public Hospital, Karaman, Turkey

${ }^{62}$ Department of Anaesthesia, Lyell McEwin Hospital, Adelaide, Australia

${ }^{63}$ University Hospital of Obstetrics and Gynecology, Sofia, Bulgaria

${ }^{64}$ Department of Medical Sciences, Section of Obstetrics and Gynecology, Azienda Ospedaliera-Universitaria Sant' Anna, University of Ferrara, Ferrara, Italy

${ }^{65}$ Ostetricia e Ginecologia Universitaria - Ospedale S. Anna e S. Sebastiano, Caserta, Italy

${ }^{66}$ Sulochana Clinic, Kolkata, India

${ }^{67}$ Department of Woman, Child and General and Specialized Surgery, University of Campania Luigi Vanvitelli, Naples, Italy

${ }^{68}$ Academic Division of Obstetrics and Gynecology, Mauriziano Umberto I Hospital, University of Turin, Turin, Italy
${ }^{69}$ Instituto de MedFetal e Diagnóstico por Imagem do Amazonas, Manaus, Brazil

${ }^{70}$ Campus Bio Medico, University of Rome, Rome, Italy

${ }^{71}$ Hospital Raul F. Larcade, Buenos Aires, Argentina

${ }^{72}$ Regional Hospital Gjakova, Kosovo, Republic of Kosovo

${ }^{73}$ Department of Obstetrics and Gynecology, Division of Neonatology, General Hospital in Prague and First Faculty of Medicine, Charles University, Prague, Czech Republic

Funding: This work did not receive any specific grant from funding agencies in the public, commercial, or not-for-profit sectors.

Compliance with Ethical Standards: The authors stated that the standards regarding research and publication ethics, the Personal Data Protection Law and the copyright regulations applicable to intellectual and artistic works are complied with and there is no conflict of interest.

\section{References}

1. Perlman S. Another decade, another Coronavirus. N Engl J Med 2020;382:760-2. [PubMed] [CrossRef]

2. World Health Organization (WHO). WHO Coronavirus (COVID-19) dashboard. [Internet]. Geneva: WHO. [cited 2020 October 26]. Available from: https://covid19.who.int

3. Di Mascio D, Khalil A, Saccone G, Rizzo G, Buca D, Liberati $M$, et al. Outcome of Coronavirus spectrum infections (SARS, MERS, COVID-19) during pregnancy: a systematic review and meta-analysis. Am J Obstet Gynecol MFM 2020;2:100107. [PubMed] [CrossRef]

4. WAPM (World Association of Perinatal Medicine) Working Group on COVID-19. Maternal and perinatal outcomes of pregnant women with SARS-COV-2 infection. Ultrasound Obstet Gynecol 2021;57:232-42. [PubMed] [CrossRef]

5. Di Mascio D, Sen C, Saccone G, Galindo A, Grünebaum A, Yoshimatsu J, et al. Risk factors associated with adverse fetal outcomes in pregnancies affected by Coronavirus disease 2019 (COVID-19): a secondary analysis of the WAPM study on COVID-19. J Perinat Med 2020;48:950-8. [PubMed] [CrossRef]

6. Huntley BJF, Huntley ES, Di Mascio D, Chen T, Berghella V, Chauhan SP. Rates of maternal and perinatal mortality and vertical transmission in pregnancies complicated by severe acute respiratory syndrome Coronavirus 2 (SARS-Co-V-2) infection: a systematic review. Obstet Gynecol 2020;136:303-12. [PubMed] [CrossRef]

7. Dubey P, Reddy SY, Manuel S, Dwivedi AK. Maternal and neonatal characteristics and outcomes among COVID-19 infected women: an updated systematic review and meta-analysis. Eur J Obstet Gynecol Reprod Biol 2020;252:490-501. [PubMed] [CrossRef]

8. Juan J, Gil MM, Rong Z, Zhang Y, Yang H, Poon LC. Effect of coronavirus disease 2019 (COVID-19) on maternal, perinatal and neonatal outcome: systematic review. Ultrasound Obstet Gynecol. 2020;56:15-27. [PubMed] [CrossRef] 
9. Allotey J, Stallings E, Bonet M, et al. Clinical manifestations, risk factors, and maternal and perinatal outcomes of coronavirus disease 2019 in pregnancy: living systematic review and meta-analysis. BMJ 2020;370:m3320. [PubMed] [CrossRef]

10. Petrilli CM, Jones SA, Yang J, Rajagopalan H, O’Donnell L, Chernyak Y, et al.; for PregCOV-19 Living Systematic Review Consortium. Factors associated with hospital admission and critical illness among 5279 people with coronavirus disease 2019 in New York City: prospective cohort study. BMJ 2020; 369:m1966. [PubMed] [CrossRef]

11. World Health Organization (WHO). Clinical management of severe acute respiratory infection when novel coronavirus (2019-nCoV) is suspected: interim guidance, 13 March 2020. Geneva: WHO; 2020.

12. Guan WJ, Ni ZY, Hu Y, Liang WH, Ou CQ, He JX, et al.; China Medical Treatment Expert Group for Covid-19.
Clinical characteristics of Coronavirus disease 2019 in China. N Engl J Med 2020;382:1708-20. [PubMed] [CrossRef]

13. Fitzpatrick KE, Tuffnell D, KurinczukJJ, Knight M. Pregnancy at very advanced maternal age: a UK population-based cohort study. BJOG 2017;124:1097-106. [PubMed] [CrossRef]

14. Waldenström U, Cnattingius S, Vixner L, Norman M. Advanced maternal age increases the risk of very preterm birth, irrespective of parity: a population-based register study. BJOG 2017;124:1235-44. [PubMed] [CrossRef]

15. D'Antonio F, Sen C, D, Mascio D, Galindo A, Villalain C, Herraiz I, et al.; WAPM Working Group on COVID-19. Maternal and perinatal outcomes in high vs low risk-pregnancies affected by SARS-COV-2 infection (Phase-2): The WAPM (World Association of Perinatal Medicine) working group on COVID-19. Am J Obstet Gynecol MFM 2021;100329. doi:10.1016/j.ajogmf.2021.100329 [PubMed] [CrossRef]

This work is licensed under the Creative Commons Attribution-NonCommercial-NoDerivs 4.0 Unported (CC BY-NC-ND4.0) License. To view a copy of this license, visit http://creativecommons.org/licenses/by-nc-nd/4.0/ or send a letter to Creative Commons, PO Box 1866, Mountain View, CA 94042, USA.

Publisher's Note: The content of this publication does not necessarily reflect the views or policies of the publisher, nor does any mention of trade names, commercial products, or organizations imply endorsement by the publisher. Scientific and legal responsibilities of published manuscript belong to their author(s). The publisher remains neutral with regard to jurisdictional claims in published maps and institutional affiliations. 